\title{
Organohalogen emissions from saline environments - spatial extrapolation using remote sensing as most promising tool
}

\author{
K. Kotte ${ }^{1}$, F. Löw ${ }^{2}$, S. G. Huber ${ }^{1}$, T. Krause ${ }^{1}$, I. Mulder ${ }^{1}$, and H. F. Schöler ${ }^{1}$ \\ ${ }^{1}$ Institute of Earth Sciences, University of Heidelberg, 69120 Heidelberg, Germany \\ ${ }^{2}$ Department of Remote Sensing, Institute of Geography, University of Würzburg, 97074 Würzburg, Germany
}

Correspondence to: K. Kotte (karsten.kotte@geow.uni-heidelberg.de)

Received: 1 July 2011 - Published in Biogeosciences Discuss.: 28 July 2011

Revised: 2 March 2012 - Accepted: 12 March 2012 - Published: 29 March 2012

\begin{abstract}
Due to their negative water budget most recent semi-/arid regions are characterized by vast evaporates (salt lakes and salty soils). We recently identified those hypersaline environments as additional sources for a multitude of volatile halogenated organohalogens (VOX). These compounds can affect the ozone layer of the stratosphere and play a key role in the production of aerosols. A remote sensing based analysis was performed in the Southern Aral Sea basin, providing information of major soil types as well as their extent and spatial and temporal evolution. VOX production has been determined in dry and moist soil samples after $24 \mathrm{~h}$. Several C1- and C2 organohalogens have been found in hyper-saline topsoil profiles, including $\mathrm{CH}_{3} \mathrm{Cl}$, $\mathrm{CH}_{3} \mathrm{Br}, \mathrm{CHBr}_{3}$ and $\mathrm{CHCl}_{3}$. The range of organohalogens also includes trans-1,2-dichloroethene (DCE), which is reported here to be produced naturally for the first time. Using MODIS time series and supervised image classification a daily production rate for DCE has been calculated for the $15000 \mathrm{~km}^{2}$ ranging research area in the southern Aralkum. The applied laboratory setup simulates a short-term change in climatic conditions, starting from dried-out saline soil that is instantly humidified during rain events or flooding. It describes the general VOX production potential, but allows only for a rough estimation of resulting emission loads. VOX emissions are expected to increase in the future since the area of salt affected soils is expanding due to the regressing Aral Sea. Opportunities, limits and requirements of satellite based rapid change detection and salt classification are discussed.
\end{abstract}

\section{Introduction}

Organic compounds containing halogens - especially chlorine - have been considered for a long time to be of industrial origin only. Volatile organohalogens (VOX) are effectively linked to atmospheric chemistry cycles, leading to potentially significant feedbacks on cloud formation, Earth's albedo and eventually the regional and global climate.

Since the middle of the 1970's over 5000 different organohalogens have been discovered to be produced by nature, involving biogeochemical, biochemical and microbial processes. This includes de-novo producers like fungi, halophilic bacteria and archaea, plants, animals, and insects (e.g. Gribble, 2010).

Relevant data on the quantity and variety of low molecular weight organohalogens in the terrestrial environment are limited. This compartment receives significant fluxes of inorganic halides via the deposition of sea salt aerosols, combustion processes, and from weathering processes of rocks as well as vertically intruding salt diapirs.

VOX have been found in natural soils as well as sediments of hyper-/saline salt lakes (Schöler and Keppler, 2003; Weissflog et al., 2005). A number of studies is dealing with the release of organohalogens from coastal marshes and other wetlands, where halogenation was suggested to depend on fungal and bacterial activity (e.g. von Glasow and Crutzen, 2007). There is also increasing evidence of an abiotic formation in soils involving humic substances and iron (Keppler et al., 2000, 2002; Huber et al., 2009). Emission budgets for longer-lived halocarbons, mainly of interest for stratospheric 
chemistry, have been published for peatlands (e.g. Dimmer et al., 2001), wetlands (Varner et al., 1999), salt marshes (Rhew et al., 2000) as well as terrestrial vegetation (Yokouchi et al., 2000).

The global source strengths of organohalogens from soils and vegetation are poorly constrained. Keppler et al. (2005) highlighted the need for a better quantification of longerlived halomethanes such as $\mathrm{CH}_{3} \mathrm{Cl}$ and $\mathrm{CH}_{3} \mathrm{Br}$ from recently discovered, additional natural terrestrial sources. For example, Wishkerman et al. (2008) elucidated the reaction of plant pectin with bromide forming $\mathrm{CH}_{3} \mathrm{Br}$. This appears abiotically at ambient temperatures and the emissions are doubled with every $5{ }^{\circ} \mathrm{C}$ rise. The natural production of $\mathrm{CH}_{3} \mathrm{Br}$ and $\mathrm{CHCl}_{3}$ has been proven by Weissflog et al. (2005) for hyper-saline sediments of Southern Russian and Kalmykian salt lakes. Huber et al. (2009) found soil $\mathrm{pH}$-levels, $\mathrm{Cl}^{-} / \mathrm{Br}^{-}$ content as well as soil organic content and structural features of the soil organic matter to be important drivers behind the biogeochemical formation of trihalomethanes. These results have important implications for the VOX release from vegetation and soils located in regions that are particularly affected by climate change (i.e. heat waves and drought). However, the global source strength remains uncertain.

First indications of the predicted climate change will appear within the next few decades. Towards the end of the 21 st century a clear increase of dry areas is expected for Middle Asia as well as for Africa, as shown in Fig. 1. For both regions the current situation of land degradation and desertification becomes more problematic due to a constant anthropogenic influence, such as overgrazing, pollution and physical overstraining. In some regions the proposed climate change will lead in consequence of higher temperature, more frequent heat waves, lower rainfall and higher evaporation to an increase in quantity and scale of hyper-saline salt lakes, salty soils and salt-dust storms, as it is now observable e.g. in Middle Asia. Due to their negative water budget most recent semi-/arid regions are characterised by vast evaporates (salt lake sediments) and salty soils.

This study aims to combine remote sensing and laboratory data on VOX production to examine the potential of satellite products for an estimate of regional VOX production rates of hyper-saline environments.

To extrapolate small-scale experiments to supra-regional and global scales it is necessary to provide spatial information on number, size, and seasonal dynamics of saline ecosystems. Satellite based remote sensing will enhance the accuracy of extrapolated small scale VOX emission data to regional scales. It is superior to simply multiplying the average production rates with the Aralkum target area, which exhibits a variability of sediments and soil types, each characterized by varying salt composition and $\mathrm{C}_{\text {org }}$ content (Dukhovny et al., 2008).

Within this study, hyper-saline ecosystems of different geographical origin, different geochemical character and different development states have been compared for their VOX production potential. The Central Asian Aralkum, whose soils have been tested for VOX production, serves as an example for a highly dynamic, spreading saline ecosystem, composed of hyper saline crusts and saline soils which appeared after desiccation of the Aral Sea (Fig. 2). A remote sensing based analysis was performed in the southern Aral Sea basin, providing information on main soil types as well as their extent and spatial distribution and temporal evolution.

The remote sensing approach counteracts distortions of simplified average production data and considers the fast evolution of soil surface as well as soil salt content and soil humidity of the Aralkum.

\section{Methods}

\subsection{Study area}

The study area (Figs. 2 and 3) is located within the autonomous Republic of Karakalpakstan (Uzbekistan), covering an area of approximately $15000 \mathrm{~km}^{2}$. With the regression of the fourth largest lake of the world, a huge saline desert emerged on the former seabed, which is called the "Aralkum" (Breckle et al., 2001). Former harbour cities like Muynak (Uzbekistan) are now located tens of kilometers away from the present shoreline. From an ecological point of view, it is considered as the world's largest area where primary succession is taking place (Wucherer and Breckle, 2001).

Decreasing water flow in the Amu Darya river (the Oxus of ancient times) caused dramatic loss of wetlands and the associated reed communities in the rich ecosystem of the Amu Darya river delta (Sivanpillai and Latchininsky, 2007). The shrinking Aral Sea exposed about $50000 \mathrm{~km}^{2}$ of its former seabed (Micklin, 2007), which shows a wide variety of different landscape and soil types. The major part of the desiccated seabed is considered as a highly unstable landscape with a high ecological hazard in terms of desertification and eolian erosion (Dukhovny et al., 2008). Salt affected areas are considered as a major source for salt and dust storms in the region and appeared after regression of the Aral Sea (Razakov and Kosnazarov, 1996; Orlovsky et al., 2001; Singer et al., 2003; Mees and Singer, 2006).

\subsection{Monitoring land cover dynamics}

Classification of Terra MODIS time-series was performed to assess the land cover dynamics in the study area between 2000 and 2008 and to monitor different stages of soil salinisation. The MOD09 8-day Surface Reflectance Data of the Terra MODIS satellite (Moderate Resolution Imaging Spectroradiometer) was chosen as primary data source. Seven spectral bands, centered at $648 \mathrm{~nm}, 858 \mathrm{~nm}, 470 \mathrm{~nm}$, $555 \mathrm{~nm}, 1240 \mathrm{~nm}, 1640 \mathrm{~nm}$, and $2130 \mathrm{~nm}$ respectively, were processed to obtain the full spectral range and improve class 


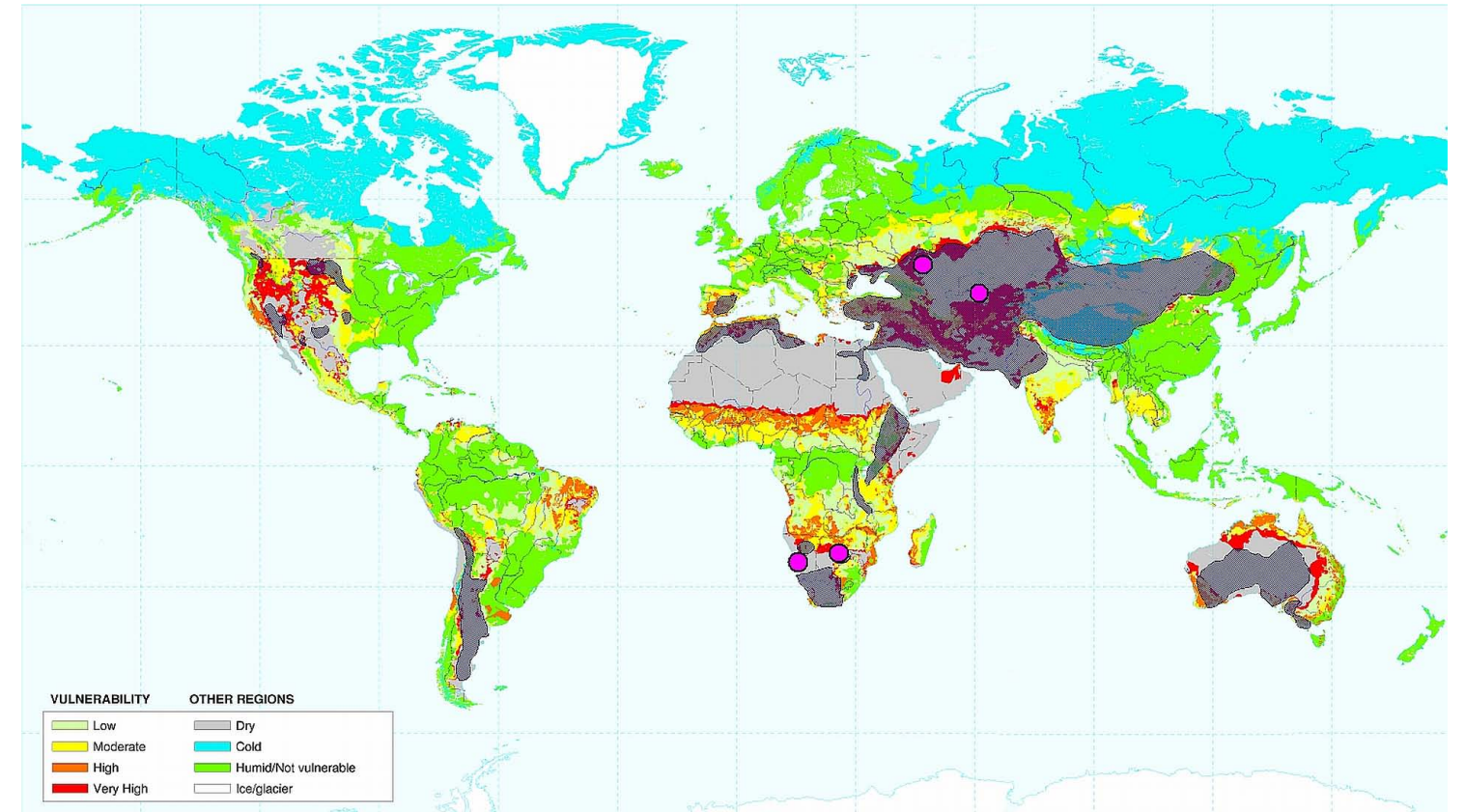

Fig. 1. Backdrop image: global desertification vulnerability (USDA-NRCS, Soil Survey Division, World Soil Resources, Washington D.C. 1996). Gray shading: global distribution of recent salt lakes and salt soils (after Williams, 2002). Pink dots indicate the study areas mentioned in this study: Aralkum desert in Central Asia, Kalmykia in southern Russia, coastal wetlands of Namibia, and inland salt flats of Botswana.
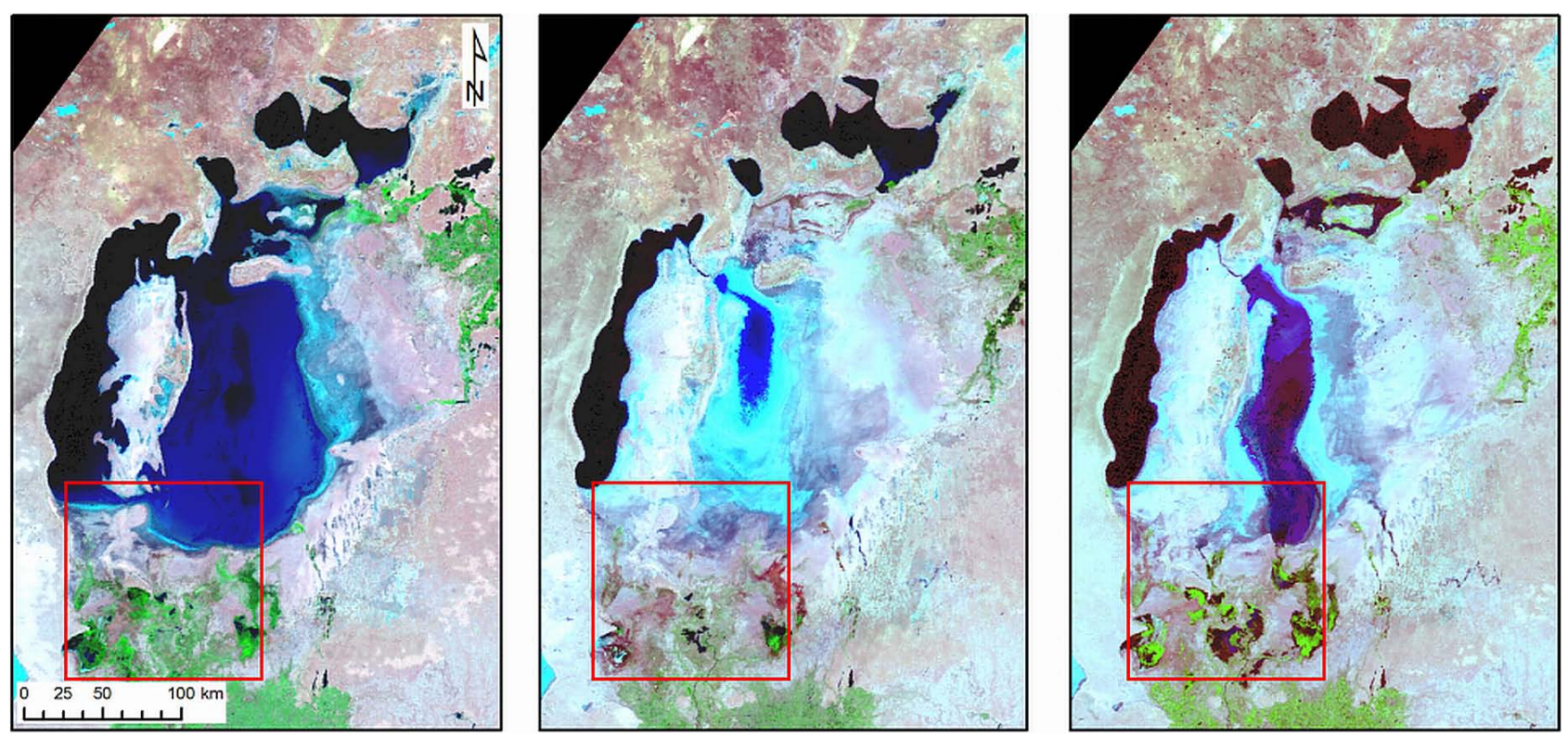

Fig. 2. Highly dynamic, spreading saline ecosystem: the Aralkum in Central Asia. Terra MODIS images acquired on July 2000, 2009 and 2010. Images displayed in false color band combination 7-2-1. Red squares indicate the study area.

separability. The almost daily availability of MODIS satellite images since the year 2000 enables recording landscape dynamics in a very high temporal resolution. Ground reference data for classification of satellite images were collected during field surveys in the study area in 2007, 2008 and
2009 in accordance to the FAO LCCS (Land Cover Classification System), whereas 650 ground reference points were collected, including photos of the sampling sides, vegetation mapping and important soil characteristics. A quality assessment of the input data was performed, using the TiSeG 


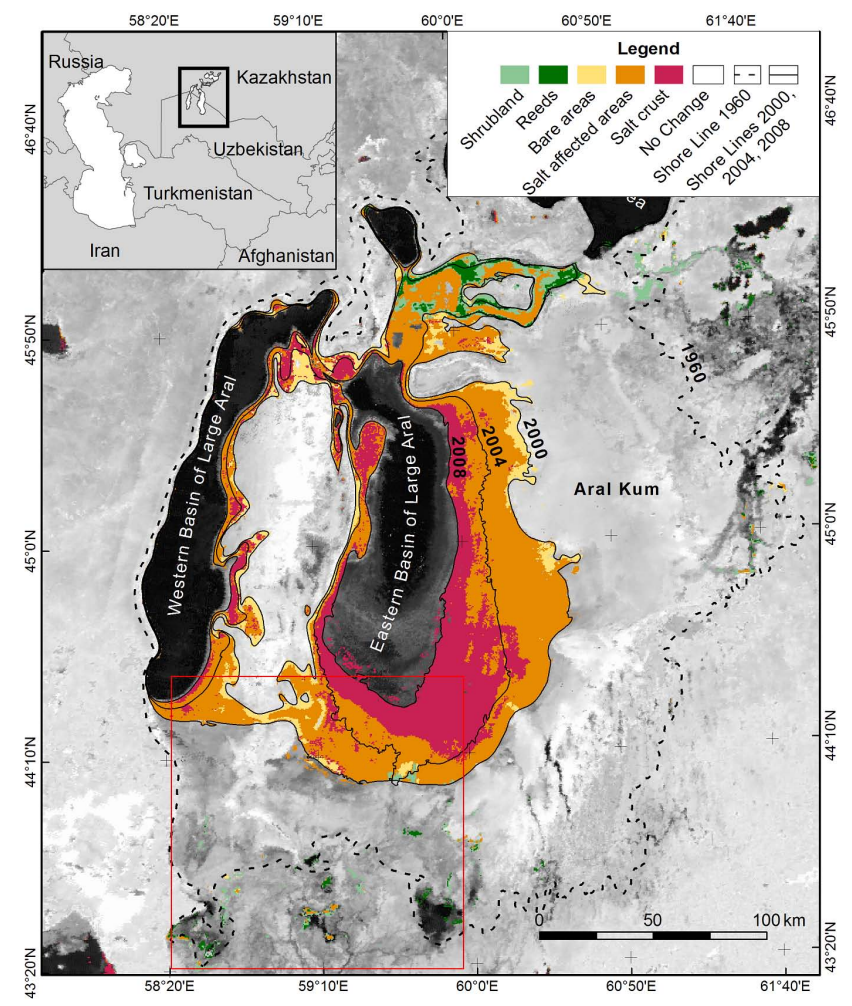

Fig. 3. Location of the study area in the southern Aral Sea Basin. The map shows the major land cover transformations that took place where the sea surface has desiccated between 2000 and 2008. The image backdrop is a Terra MODIS scene acquired on 20 July 2009. Red square indicates the study area.

software (Time Series Generator) (Colditz et al., 2008). Additional input information for the classification procedure was provided through the calculation of the NDVI (Normalized Differentiated Vegetation Index) and several band ratios where tested and evaluated for their potential to improve discriminating salt affected areas. Besides data noise, time series exhibit significant temporal autocorrelation. In order to reduce the redundancy in feature space, metrics (basic statistics such as mean, standard deviation, minimum, maximum, and range) were calculated and further used as baseline dataset for the classification. Decision trees (DT) were found to be the most suitable method for classifying the input data, and have successfully been applied in other studies (DeFries et al., 1995; Hansen et al., 2000). The classification of the time series was conducted with the QUEST algorithm (Quick Unbiased Efficient Statistical Tree) (Loh and Shih, 1997), which is implemented in the software add-on "RuleGEN 1.02 " running in the standard image processing environment "ENVI 4.7" (ITT Visual Information Solutions).

The classification results were used to perform a postclassification change-detection analysis for the time steps 2000-2004, 2004-2008 and 2000-2008. The approach used in this study provides "from-to" change information and the kind of landscape transformation that have occurred. The land-cover change areas between the different classes were then calculated. Validation was performed using an independent sample of validation points to assess classification accuracy. Validation points from 2008 were measured directly in the field, whereas for 2000 and 2004, validation points were randomly generated and evaluated visually using Landsat TM imagery and NDVI temporal signatures. For further details of the method see Löw et al. (2012).

\subsection{Soil chemistry and VOX emission}

Soil samples for VOX analysis have been taken in May 2009. After pre-screening certain soil types in the study area using Landsat 5 TM classification based soil maps (Dukhovny et al., 2008), specific sample sites have been selected along several transects, focusing on unaffected natural topsoil. Topsoil profiles $(0-2 \mathrm{~cm})$ were sampled for each site, where available the soil/salt crusts were additionally sampled between $0-0.5 \mathrm{~cm}$. Sampling sites were positioned by means of GPS measurements including photos of the sampling sites, soil surface characterization and geo-botanic mapping by a standardized form sheet based on LCCS.

Soil samples were kept cool and shipped to Heidelberg (Germany), frozen at $-26^{\circ} \mathrm{C}$, freeze-dried, milled and sieved (mesh $<315 \mu \mathrm{m}$ ). XRD analyses were performed applying a Bragg-Brentano powder diffractometer (Philips PW 3020 Goniometer) with secondary beam monochromator. Soil organic carbon content is calculated from total carbon content and inorganic carbon (carbonate), using a CS analyzer (Leco SC-1444DR), and a carbonate bomb (Müller and Gastner, 1971), respectively.

The method to determine the VOX formation in topsoil samples followed the procedure described by Huber et al. (2009). In brief, dried and milled soil samples were transferred to $20 \mathrm{ml}$ headspace glass vials and incubated for $24 \mathrm{~h}$ at $40^{\circ} \mathrm{C}$ in the dark. The VOX production has been determined using a custom-made purge \& trap system, connected to a gas chromatograph with mass spectrometer (Varian STAR 3400 GC and Saturn 2000 ion trap MS). The setup describes the general VOX production potential. It does not enable direct correlation to emissions, but allows for a rough estimation of resulting emission loads. To discover the effect of soil humidity different assays have been performed, adding distilled water to selected soil samples or directly testing the dried soil (Huber et al., 2009). Detection limits have been determined to $0.1-0.01 \mathrm{ng} \mathrm{g}^{-1}$ dry soil, depending on species and matrix.

Preconditioning the samples enables to compare the soil production potential for different sample depths, locations and geographical regions and allows for statistical evaluation of possible drivers. The applied sample preparation suppresses the majority of biogenic VOX producers, such as bacteria, algae and archaea. Based on literature (e.g. Morley et al., 1983; Islam et al., 1997) a single freezing period of more than $24 \mathrm{~h}$ with temperatures of less than $-20^{\circ} \mathrm{C}$ 
Table 1. Matrix of land cover change derived from MODIS time series classification. Area statistics for 2000, 2004 and 2008.

\begin{tabular}{|c|c|c|c|c|c|c|c|}
\hline \multicolumn{2}{|r|}{ Land cover class } & \multicolumn{2}{|c|}{2000} & \multicolumn{2}{|c|}{2004} & \multicolumn{2}{|c|}{2008} \\
\hline Typ & Description & $\left(\mathrm{km}^{2}\right)$ & $(\%)$ & $\left(\mathrm{km}^{2}\right)$ & $(\%)$ & $\left(\mathrm{km}^{2}\right)$ & $(\%)$ \\
\hline Shrubland & $\begin{array}{l}\text { Mainly shrubs (e.g. Haloxylon aphyllum, } \\
\text { Tamarix sp.), vegetation coverage }>15 \%\end{array}$ & 4493 & 30.1 & 3828 & 25.6 & 5649 & 37.8 \\
\hline Reed & $\begin{array}{l}\text { Reeds, mainly dominated by Phragmites sp., } \\
\text { partly with other vegetation (mostly shrubs) }\end{array}$ & 2961 & 19.8 & 3891 & 26.0 & 1737 & 11.6 \\
\hline Bare Area & $\begin{array}{l}\text { Bare soils and unconsolidated materials, } \\
\text { sand sheets and dunes, soils with scattered } \\
\text { vegetation, vegetation coverage }<15 \%\end{array}$ & 2261 & 15.1 & 1974 & 13.2 & 3024 & 20.2 \\
\hline Salt Soil & Salt affected soils (e.g. Solonchaks, Takyrs) & 2014 & 13.5 & 3036 & 20.3 & 3707 & 24.8 \\
\hline Salt Crust & Salt crusts surrounding Aral Sea shoreline & 320 & 2.2 & 695 & 4.7 & 717 & 4.8 \\
\hline Water & Shallow lakes, reservoirs and the Aral Sea & 2888 & 19.3 & 1514 & 10.1 & 105 & 0.7 \\
\hline Total & & 14940 & 100 & 14940 & 100 & 14940 & 100 \\
\hline
\end{tabular}

results in $60 \%$ mortality of soil microorganisms. Depending on species, environment and temperature the microbial population might recover within several days. However, the microbial residues $\left(\mathrm{C}_{\text {org }}\right.$ source $)$ remain in the sample and will be exposed to geochemical reactions.

Depending on sample location, the low organic content of saline sediments partly originates from algae/bacterial mats. Based on experiments by Weissflog et al. (2005) one would expect even higher emission rates when incubating unprepared samples for several weeks or months.

\section{Results and discussion}

\subsection{Change detection and soil condition}

Using MODIS time series and supervised image classification, different stages of salinization were classified for the years 2000, 2004 and 2008, ranging from salt crusts within a narrow stripe adjacent to the sea, to extensive Solonchaks and almost salt free sand sheets. Overall accuracies were consistently high with $82.8 \%, 81.5 \%$ and $79.5 \%$, and Kappa statistics of $78 \%, 77 \%$ and $73 \%$, respectively. It is shown that the recession of the Aral Sea results in a quick build up of extensive salt crust directly adjacent to the sea. Almost all of these salt pans covered by salt crusts developed into a series of different salt soil types (e.g. Solonchak, Takirs) and then, in some parts of the area, into almost sand free bare areas. This trend was found to occur within $8 \mathrm{yr}$ at some locations, demonstrating that a significant proportion of the former seabed features highly unstable surface types (Fig. 3). The changing hydrological situation of wetlands over the years is obvious (Fig. 2). Important types of land cover change between 2000-2004 and 2004-2008 were "water to salt soils", "water to salt crusts" and the conversion of salt soils to bare area (Table 1).
The composition of main minerals, calculated through XRD semi-quantitative analysis is given in Fig. 4. All locations, except $\mathrm{T} 3$, are dominated by $\mathrm{SiO}_{2}$ minerals (quartz: 47-83\%). Location T3 itself is situated within the rapid developing salt flats surrounding the residual water body of Aral Sea and is dominated by precipitated salts (sulphates $35 \%$, halides $32 \%$, carbonates $20 \%$ ). Compared to that, T6 represents a typical sandy topsoil, dominated by $83 \%$ silicates with only $10 \%$ sulfates and $7 \%$ carbonates. The area surrounding T6 dried out very recently and is a region that is influenced by accumulation of sand and aeolian dust. Locations T7 and T5 can be seen in an intermediate class with $\sim 50 \%$ silicates, versus $\sim 20 \%$ carbonates and $\sim 15 \%$ halide. Both sites are being flooded regularly (T7, storage lake Sudochie) in other words periodically influenced by increased soil humidity and elevated level of saline groundwater (T5, next to old, temporally flooded dam). Through capillary forces these humid soils accumulate salt at the soil surface, forming distinct crusts of several millimetre thickness.

Soil organic content $\left(\mathrm{C}_{\text {org }}\right)$ varied between $0.2 \%$ and 0.5 weight $\%$. Highest organic values were found in dry sediments of the water reservoir Sudochie at site T7 with 1,6\%. Accordingly, T7 has to be compared carefully with other "salt soils" in the study area - e.g. T5 and T10, which gave a similar RS-signal but provide different hydrological features.

\subsection{VOX production in Aralkum samples}

VOX emission experiments were performed for each $0-2 \mathrm{~cm}$ soil sampling interval. As shown in Fig. 4 most soil samples produce trans 1,2-dichloroethene (DCE) in the range of $0,1 \mathrm{ng} \mathrm{g}^{-1}$ soil dry weight (DW), within $24 \mathrm{~h}$ after humidification. DCE is widely known as breakdown or degradation product of anthropogenic VOX pollution, particularly in groundwater and soil. Our data (Fig. 4 and Table 3) reveal the frequent formation of DCE in several saline soils from 


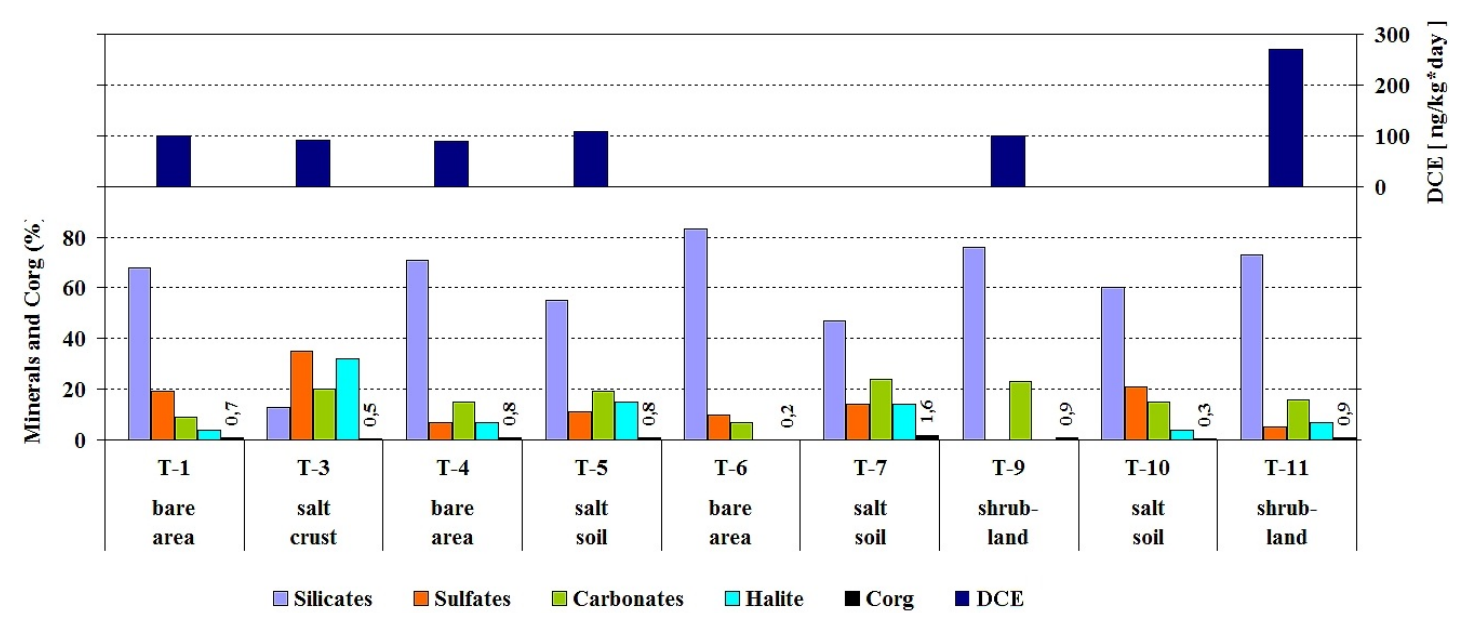

Fig. 4. Mineral content and $\mathrm{C}_{\text {org }}$ versus DCE production. Samples of topsoil layer 0-2 cm (including crusts), incubated for $24 \mathrm{~h}$ after adding water. DCE determination by purge \& trap headspace GC-MS. Production rates are given in $\left[\mathrm{ng} \mathrm{kg}^{-1} *\right.$ day]. Land cover classes of location

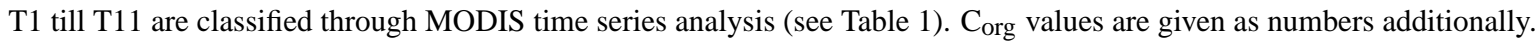

Middle Asia, Southern Africa and Southern Russia, but the confirmation of the underlying production mechanism is still under investigation. DCE might also be produced through degradation of higher chlorinated precursors such as tri-, tetrachloroethene and trichloroethane, since recent research has revealed chemically-precipitated ferrous iron to act as an abiotic active reductant for VOX (e.g. Brown et al., 2009).

Regarding Fig. 4 the successively formed sandy soils of the locations T6 and T10 do not show any DCE formation, which possibly can be explained by their very low $\mathrm{C}_{\mathrm{org}}$ content. Surprisingly soil T7, which displays highest $\mathrm{C}_{\text {org }}$ content and provides favourable high soil humidity in the field does not produce any DCE under laboratory conditions. Whereas site T11, a rather sandy soil type, but several ten years matured after desiccation, reached highest DCE values. T11 is situated southeast of Muynak and lies within the former Amu Darya river delta. Desiccation after 1970-1980 and regularly flooding during springtime was followed by the usage for livestock feeding. The mechanism of DCE formation and possible inhibiting factors remain unclear.

For a rough estimate of regional DCE production potential, the land cover class data of Table 1 are combined with the DCE formation data of Fig. 4. Calculated DCE production data for the years 2000, 2004 and 2008 are shown in Table 2. Production data refer to a $24 \mathrm{~h}$ production time under the favourable condition of a moist soil system (e.g. after flooding or rain events) and elevated summer temperatures of $25-35^{\circ} \mathrm{C}$ air temperature; climate conditions that may result in topsoil temperatures of up to $55^{\circ} \mathrm{C}$. Due to difficult sampling conditions close to the remaining water body, no samples could be taken for the land cover class "Water". Land cover class "Reed" was not included as well. For class "Shrubland" and "Bare Area" the corresponding emission loads vary between the sample sites considerably. This can be explained by grouping different soil types to one soil class (according to the method used) as well as fractional misinterpretation of soil signals by MODIS. The measured plots were selected in such a way that they represent the spatial variation of land cover classes and the variations in VOX production are therefore to be expected. Mapping specific features like salt quality, organic content or humidity to assign soil sub classes can not be realized without a hyperspectral data approach (e.g. Schmid et al. 2004; Dehaan and Taylor, 2002). Herein the limits of the applied method become evident. To demonstrate the limits of MODIS data Fig. 5 contains spectral signature variations of main land cover classes in contrast to laboratory data of spectral profiles for gypsum, halite, calcium carbonate, sodium bicarbonate, and sodium sulphate data taken from Metternicht and Zinck (2003).

Hypothetically, based on the $0-2 \mathrm{~cm}$ data a productive day in 2008 could have led to a notable production up to a total of $23 \mathrm{~kg}$ DCE for the research area of $15000 \mathrm{~km}^{2}$. This number increases drastically when applying the method to the remaining salt affected soils of the $50000 \mathrm{~km}^{2}$ ranging Aralkum and the surrounding salt affected soils. Expanding the production time to the whole spring season, with its high temperatures but still moist soil system, will further increase the DCE production. Enhanced production rates can be expected in the future when remaining hyper-saline water bodies of the Aral Sea dry out (Micklin, 2010). Including emission data of the deeper soil layers will potentially top up the overall production. Since DCE is only one of a range of chemical substances, the total VOX production loads could potentially increase significantly.

Regional and global emission models often base on a relatively small number of plots chosen as representative areas for large heterogeneous or fragmented landscapes (e.g. small farming). That way, the given sample frequency for the relatively homogenous bottom of the Aral Sea is not very different from other experiments focusing on e.g. $\mathrm{CH}_{4}$, $\mathrm{NOx}$ or 
Table 2. Estimated production of trans 1,2-DCE for the research area (ca. $15000 \mathrm{~km}^{2}$ ) based on 0-2 cm soil profile data. Determined DCE production within $24 \mathrm{~h}$ after humidification of the soil sample. Production rates are given for each land cover class in $\mathrm{g}$ DCE/covered area and day.

\begin{tabular}{|c|c|c|c|c|c|c|c|c|}
\hline \multirow{2}{*}{\multicolumn{2}{|c|}{$\begin{array}{l}\text { Land cover } \\
\text { class and } \\
\text { corresponding site }\end{array}$}} & \multirow[t]{2}{*}{$\begin{array}{r}\text { DCE } \\
\text { production } \\
{\left[\mathrm{mg} \mathrm{km}^{-2} * \mathrm{~d}\right]}\end{array}$} & \multicolumn{3}{|c|}{$\begin{array}{c}\text { Land cover area } \\
{\left[\mathrm{km}^{2}\right]}\end{array}$} & \multicolumn{3}{|c|}{$\begin{array}{l}\text { DCE production } \\
{[\mathrm{g} / \text { cover area } * \mathrm{~d}]}\end{array}$} \\
\hline & & & 2000 & 2004 & 2008 & 2000 & 2004 & 2008 \\
\hline \multirow{2}{*}{ Shrubland } & T-9 & 1004 & 4493 & 3828 & 5649 & 4511 & 3843 & 5672 \\
\hline & $\mathrm{T}-11$ & 2703 & & & & 12144 & 10347 & 15269 \\
\hline \multirow[t]{2}{*}{ Reed } & no site & - & 2961 & 3891 & 1737 & - & - & - \\
\hline & $\mathrm{T}-1$ & 991 & 2261 & 1974 & 3024 & 2241 & 1956 & 2997 \\
\hline \multirow[t]{2}{*}{ Bare Area } & $\mathrm{T}-4$ & 889 & & & & 2010 & 1755 & 2688 \\
\hline & T-6 & n.d. & & & & n.d. & n.d. & n.d. \\
\hline \multirow{3}{*}{ Salt Soil } & $\mathrm{T}-5$ & 1090 & 2014 & 3036 & 3707 & 2196 & 3310 & 4042 \\
\hline & $\mathrm{T}-7$ & n.d. & & & & n.d. & n.d. & n.d. \\
\hline & $\mathrm{T}-10$ & n.d. & & & & n.d. & n.d. & n.d. \\
\hline \multirow{2}{*}{$\begin{array}{l}\text { Salt Crust } \\
\text { Water }\end{array}$} & T-3 & 915 & 320 & 695 & 717 & 293 & 636 & 656 \\
\hline & no site & - & 2888 & 1514 & 105 & - & - & - \\
\hline \multirow{3}{*}{\multicolumn{2}{|c|}{$\begin{array}{l}\text { Sum high } \\
\text { Sum mid } \\
\text { Sum low }\end{array}$}} & & & & & 16873 & 16249 & 22963 \\
\hline & & & & & & 9009 & 9544 & 13057 \\
\hline & & & & & & 4803 & 4479 & 6327 \\
\hline
\end{tabular}

n.d. = not detectable, “-”= not measured

Table 3. Typical VOX emission characteristic of saline soils and sediments of different origin using purge-and-trap GC/MS analysis; $24 \mathrm{~h}$ incubation time under condition of moisten or dry saline sediment $\left[\mathrm{ng} \mathrm{m}^{-2}\right]$.

\begin{tabular}{|c|c|c|c|c|c|}
\hline & & $\begin{array}{r}\text { Uzbekistan } \\
\text { Southern Aral } \\
\text { Sea }\end{array}$ & $\begin{array}{r}\text { South Russia } \\
\text { Volgograd } \\
\text { region }\end{array}$ & $\begin{array}{r}\text { Namibia } \\
\text { Walfishbay }\end{array}$ & $\begin{array}{r}\text { Botswana } \\
\text { Makgadigkadi } \\
\text { Pan }\end{array}$ \\
\hline Site description & & $\begin{array}{r}\text { endorheic basin, } \\
\text { partly seasonally } \\
\text { flooded }\end{array}$ & $\begin{array}{l}\text { salt pan (from } \\
\text { diaper), seasonally } \\
\text { covered with water }\end{array}$ & $\begin{array}{r}\text { dry river mouth, } \\
\text { maritime } \\
\text { coastline }\end{array}$ & $\begin{array}{r}\text { dry salt pan, } \\
\text { seasonally covered } \\
\text { with water/grass }\end{array}$ \\
\hline \multirow[t]{2}{*}{ GPS } & & $43^{\circ} 58^{\prime} 46 \mathrm{~N}$ & $49^{\circ} 7^{\prime} 50 \mathrm{~N}$ & $23^{\circ} 5^{\prime} 30 \mathrm{~S}$ & $20^{\circ} 32^{\prime} 12 \mathrm{~S}$ \\
\hline & & $59^{\circ} 0^{\prime} 24 \mathrm{E}$ & $46^{\circ} 41^{\prime} 35 \mathrm{E}$ & $14^{\circ} 27^{\prime} 35 \mathrm{E}$ & $25^{\circ} 58^{\prime} 31 \mathrm{E}$ \\
\hline $\mathrm{pH}$ soil crust & & $8.5-10$ & $6.9-8.3$ & $7.8-9.0$ & $9.5-10,3$ \\
\hline Conc. range $\mathrm{Cl}^{-}\left[\mathrm{g} \mathrm{kg}^{-1}\right]$ & & $6.1-120$ & $22-51$ & $17-81$ & $25-82$ \\
\hline Conc. range $\mathrm{Br}^{-}\left[\mathrm{mg} \mathrm{kg}^{-1}\right.$ & & n.d. & $112-315$ & $43-312$ & 64-204 \\
\hline $\mathrm{Cl}^{-} / \mathrm{Br}^{-}$(molar ratio) & & - & $260-450$ & $470-990$ & $780-990$ \\
\hline Chloromethane & $\mathrm{CH}_{3} \mathrm{Cl}$ & n.d. & $15240 *$ & $14410 *$ & n.d. \\
\hline Bromomethane & $\mathrm{CH}_{3} \mathrm{Br}$ & n.d. & $1040^{*}$ & $1160 *$ & n.d. \\
\hline Tribromomethane & $\mathrm{CHBr}_{3}$ & n.d. & $2570 *$ & n.d. & n.d. \\
\hline Trichloromethane & $\mathrm{CHCl}_{3}$ & 4640 & 1480 & 3620 & 2190 \\
\hline Dibromochloromethane & $\mathrm{CHBr}_{2} \mathrm{Cl}$ & n.d. & n.d. & n.d. & 9800 \\
\hline Dichlorobromomethane & $\mathrm{CHBrCl}_{2}$ & n.d. & n.d. & n.d. & n.d. \\
\hline Trans-1,2-Dichloroethene & $\mathrm{C}_{2} \mathrm{H}_{2} \mathrm{Cl}_{2}$ & 2640 & n.d. & 20700 & 8270 \\
\hline Trichloroethene & $\mathrm{C}_{2} \mathrm{HCl}_{3}$ & 290 & n.d. & n.d. & 1290 \\
\hline Tetrachloroethene & $\mathrm{C}_{2} \mathrm{Cl}_{4}$ & n.d. & n.d. & 430 & 360 \\
\hline
\end{tabular}

* Detected under dry condition n.d. = not detectable. All other data points have been detected under moist condition. 


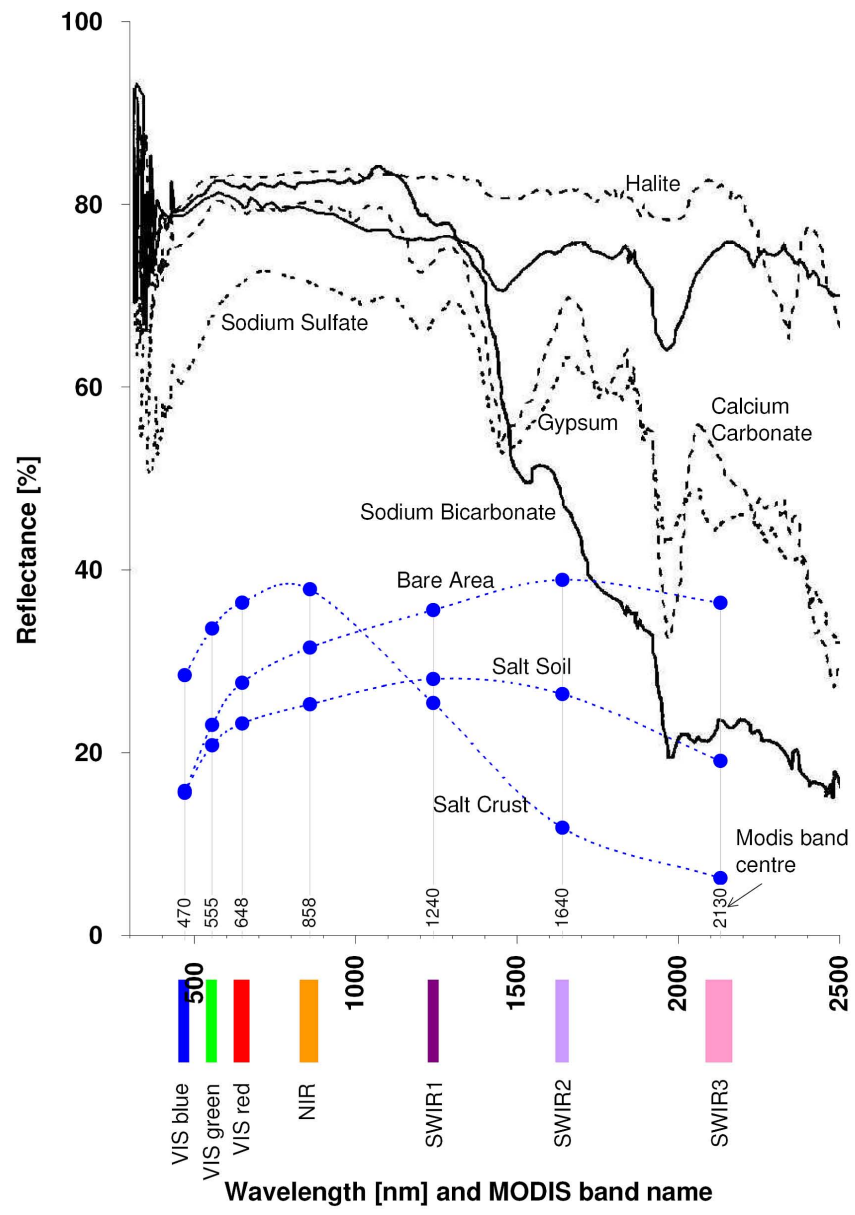

Fig. 5. Spectral signature variations of main land cover classes (bare area, salt soil and salt crust). Data recorded from pixels covering the soil sampling sites respectively pixels selected for training of the image classifier algorithm. Reflectance measurements (blue dots) were interpolated for better visual readability (blue dotted lines). For comparison with laboratory data the image backdrop shows spectral profiles of gypsum, halite, calcium carbonate, sodium bicarbonate, and sodium sulphate in the visible, near, and mid-infrared (400-2500 nm). Data source: Metternicht and Zinck (2003); recorded by the GER 3700 Spectroradiometer.

$\mathrm{CO}_{2}$ production from much more inhomogeneous soil systems. Categorical land cover classes have been used before to extrapolate emission rates of certain gases by e.g. Hines et al. (1993), Stow et al. (1998), Zhang et al. (2011), Bubier et al. (2005) and Melack et al. (2004).

\subsection{Comparing samples from Aralkum, southern Africa and southern Russia}

VOX production data for saline sediments of southern Africa, as well as southern Russia and the Aralkum are compared in Table 3. Sampling procedure and analytical method for these locations are similar to the experiments performed in the $\mathrm{Ar}$ - alkum. Saline sediments at the Namibian coastline as well as the Makgadikgadi salt flats in central Botswana outrange the DCE production of the former sediments of Aral Sea. $\mathrm{CHCl}_{3}$ occurs consistently, whereas others seem to be specific to one location or special soil conditions. Indications for a $\mathrm{pH}$-dependent production mechanism can be derived from Table 3 as well, which meets the findings of Huber et al. (2009). As expected the production of Br-VOX can be correlated to soils bromide content. Inland salt lakes that are fed by ancient marine salt deposits (e.g. Southern Russia) often show elevated bromide content and corresponding $\mathrm{Br}$ VOX emissions. Saline environments that are mainly fed by erosion processes often show relatively low bromide content (e.g. Aral sea). No brominated VOX could be found for the Aralkum, which correlates to the low concentration of bromide in the soil samples. Substantial amounts of brominated VOX have been found in saline sediments that are influenced by (ancient) sea water, brackish ground water or sea spray (e.g. Namibia, Southern Russia, Botswana).

Interestingly some compounds $\left(\mathrm{CH}_{3} \mathrm{Cl}, \mathrm{CH}_{3} \mathrm{Br}\right)$ were found under dry conditions, others exclusively for moist soil (compare Table 3). The underlying formation scheme for a thermolysis production might have similarities to the pectin reaction reported by Wishkerman et al. (2008) and offers a possible pathway of degradation of biotic material (e.g. algae mats) that remains in the topsoil during dry seasons. All in all, Table 3 and literature data indicate the main factors for the VOX production mechanism to be $\mathrm{pH}$-level, soil organic content as well as salt content/composition (halide, sulfate, carbonate) and soil humidity (water content) - (e.g. Huber et al., 2009; Weissflog et al., 2005)

Comparison of the VOX species composition, shown in Table 3, discloses a incoherency of possible formation mechanisms between the sites and per VOX species - caused by different geochemical and microbial conditions. Different VOX production rates and composition under dry versus moist conditions do not automatically allow differentiating between a geochemical or a microbial mechanism since both rely on moist environments. It is not yet clear to which extent microbial and geochemical production mechanisms contribute for each sample site, respectively can not be compared between the sites.

Based on our findings an efficient VOX production is no longer bound to rain events and flooding only, but becomes conceivable throughout the whole year, depending on climatic factors and geographical region. The results emphasize the global relevance of hyper-saline environments as potential source areas for VOX formation.

Consequently, the question emerges whether and how, recent and future saline terrestrial ecosystems will have an impact on the global VOX budget, including seasonal effects like dissolution of halite minerals during rain events followed by recrystallisation, as well as annually shifting soil temperature and soil humidity. 


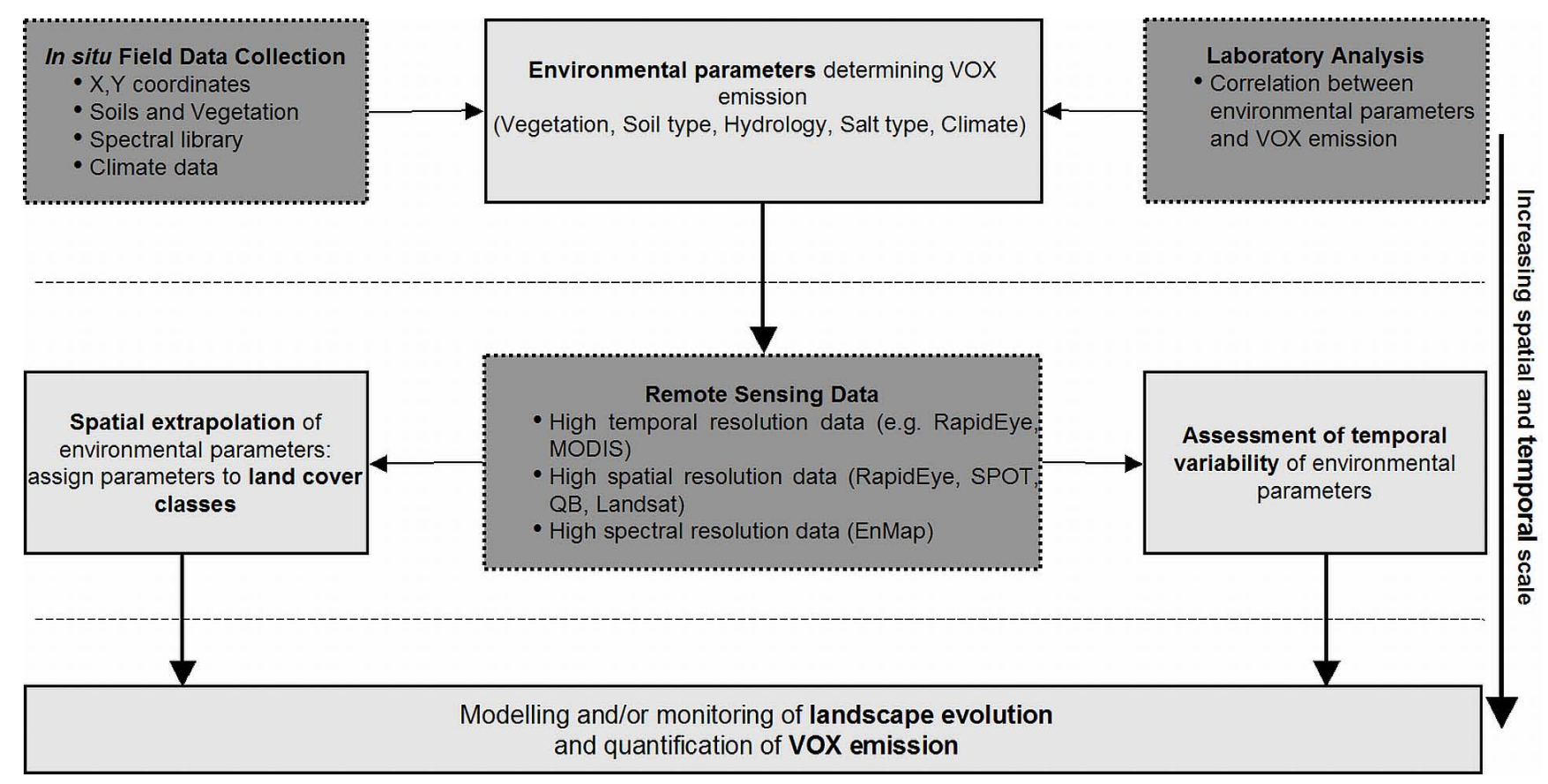

Fig. 6. Proposed flow chart for extrapolation of VOX emission from soil measurements to larger scales.

Literature data on soil VOX emission is mainly based on soils from boreal zones, humid tropics, temperate mid latitudes and sub-polar regions. Little or no information is available for dry mid latitudes and dry sub-/tropical regions (e.g. Bubier et al., 2005). Albers et al. (2011) and others discuss the spatial variability of VOX production in northern Europe, revealing spatial heterogeneities of the VOX emission as an important issue. In contrast to temperate soils the dried-out Aral Sea exposes sandy-clayey sediments, which are often covered by salt crusts. Thus the existing knowledge from temperate soils can not be transferred easily to dry hyper-/saline sediments with usually no $\mathrm{O}$, A and B horizon and $\mathrm{C}_{\text {org }}$ contents of $<2 \%$. For this reason, existing models on the influence of soil type and texture on VÒX emission from production data cannot be adapted to (hyper)saline terrestrial ecosystems to estimate their emission loads. Our scenario describes the special situation of humidification and slurrying the upper soil layer/crust during rain events, which alters texture and porosity of dry soil. VOX are effectively stripped from the resulting hyper-/saline mixture by salting out effect and temperature effects. The same effects will take place in salt flats mentioned in Table 3, covering hundreds of square kilometres with surface temperatures of up to $55^{\circ} \mathrm{C}$. Thus, the spontaneous emission of VOX from topsoil sediments becomes very likely.

\section{Conclusions}

There is no analytical large-scale method available for determining VOX with appropriate sensitivity. Open Path FT-IR Spectroscopy might work for some chlorinated organic compounds, but is limited to mid to high concentration in the range of $\mathrm{mg} \mathrm{m}^{-3}$. Airborne measurements often fail due to administrative obstacles and high expenses. Other methods lead to imbalances of the soil system by sampling or housing, in which chamber experiments are difficult to handle in landscapes with little or no infrastructure. Therefore, currently the best approach is to recourse to laboratory based VOX analysis from soil core samples, ideally supported by field chamber experiments. The question remains, how to extrapolate VOX emissions from small-scale soil measurements to landscape scale. Here we have shown that synergistic use of VOX emission data and remote sensing products may be a suitable approach for estimating the VOX production in saline ecosystems, as well as extrapolation of field measurements to larger scales. Our setup reproduces a shortterm change in climatic conditions starting from dried-out saline soil, humidified during rain events or flooding. It describes the general VOX production potential and allows a rough estimate of the emission load.

At this stage the applied remote sensing method contains uncertainties regarding the accuracies of land cover classification with focus on salt composition and soil humidity. Several salt types show different spectral profiles (Fig. 5), which can be measured by means of remote sensing data (Ben-Dor et al., 2002; Drake, 1995; Hunt et al., 1972). Highly saline 
soils can be distinguished from low or even non-saline soils (Metternicht and Zinck, 2003, 2009). But comparing field and laboratory data much lower reflectance values for real samples becomes apparent (Fig. 5), which might be caused in the mixed signal problem of the $500 \times 500 \mathrm{~m}$ MODIS pixels (plant and soil fractions between salt crusts). Furthermore different surface conditions and coarseness affects back radiation. Since the emission of VOX is mainly connected to surface salt composition, a higher level of detail is needed to calculate the soil classes with sufficient accuracy.

To detect rapid changes in surface composition and land cover of saline environments, with adequate precision and at different temporal and spatial scales is a future challenge (e.g. salt type, dissolving and re-crystallization following rain events). The application of hyper spectral data (e.g. EnMap) becomes essential to meet the problem of MODIS's small number of spectral bands, which shield pronounced spectral information, such as curve parameter and attributes (Figs. 5 and 6). In order to enhance understanding of smallscale surface heterogeneities and their influence on regional VOX emission rates, a multi-scale classification system is needed, including sensors with different spatial and temporal resolution. A possible methodological procedure is summarized in Fig. 6.

Special attention has to be paid, when correlating environmental parameters with VOX emission and when assigning VOX emission to distinct land cover classes, which are directly or indirectly influenced by these parameters and distinguishable by means of remote sensing.

Acknowledgements. This study was carried out within the context of the HALOPROC project funded by the DFG (German Research Foundation, Research Unit 763). We would like to thank the Friedrich-Ebert Foundation for the scholarship to F. Löw and the GIZ (German Agency for International Cooperation) for logistical support of the ground surveys in Uzbekistan.

Edited by: D. Fernández Prieto

\section{References}

Albers, C. N., Jacobsen, O. S., Flores, É. M. M., Pereira, J. S. F., and Laier, T.: Spatial variation in natural formation of chloroform in the soils of four coniferous forests, Biogeochemistry, 103, 317334, 2011.

Ben-Dor, E.: Quantitative remote sensing of soil properties, Adv. Agro. Academic Press, 75, 173-243, doi:10.1016/S00652113(02)75005-0, 2002.

Breckle, S.-W., Wucherer, W., Agachanjanz, O., and Geldyer, B.: The Aral Sea crisis region, in: Sustainable land use in deserts, edited by: Breckle, S. W., Veste, M., and Wucherer, W., Springer, Berlin Heidelberg New York, 27-37, 2001.

Brown, R. A., Mueller, J. G., Seech, A. G., Henderson, J. K., and Wilson, J. T.: Interactions between biological and abiotic pathways in the reduction of chlorinated solvents, Remediation, Winter, 2009.
Bubier, J., Moore, T., Savage, K., and Crill, P.: A comparison of methane flux in a boreal landscape between a dry and a wet year, Global Biogeochem. Cy., 19, GB1023, doi:10.1029/2004GB002351, 2005.

Colditz, R. R., Conrad, C., Wehrmann, T., Schmidt, M., and Dech, S.: TiSeG: flexible software tool for time-series generation of MODIS data utilizing the quality assessment science data set, IEEE T. Geosci. Remote Sens., 46, 3296-3308, 2008.

DeFries, R., Hansen, M., and Townshend, J. R. G.: Global discrimination of land cover types from metrics derived from AVHRR pathfinder data, Remote Sens. Environ., 54, 209-222, 1995.

Dehaan, R. and Taylor, G. R.: Image-derived spectral endmemders as indicators of salinisation, Int. J. Remote Sens., 24, 775-794, 2002.

Dimmer, C. H., Simmonds, P. G., Nickless, G., and Bassford, M. R.: Biogenic fluxes of halomethanes from Irish peatland ecosystems, Atmos. Environ., 35, 321-330, 2001.

Drake, N. A.: Reflectance spectra of evaporite minerals (400-2500 $\mathrm{nm}$ ). Applications for remote sensing, Int. J. Remote Sens., 16, 2555-2571, 1995.

Dukhovny, V. A., Navratil, P., Rusiev, I., Stulina, G., and Roshenko, Y. E.: Comprehensive remote sensing and ground based studies of the dried Aral Sea bed, Tashkent: Scientific Information Center ICWC, 2008.

Gribble, G. W.: Naturally occurring organohalogen compounds - A comprehensive update, Springer Verlag, Wien New York, 2010.

Hansen, M. C., DeFries, R. S., Townshend, J. R. G., and Sohlberg, R. A.: Global land cover classification at $1 \mathrm{~km}$ spatial resolution using a classification tree approach, Int. J. Remote Sens., 21, 1331-1364, 2000.

Hines, M. E., Pelletier, R. E., and Crill, P. M., Emissions of sulfur gases from marine and freshwater wetlands of the Florida Everglades: Rates and extrapolation using remote sensing, J. Geophys. Res., 98, 8991-8999, 1993.

Huber, S. G., Kotte, K., Schöler, H. F., and Williams, J.: Natural abiotic formation of trihalomethanes (THM) in soil: Results from laboratory studies and field samples, Environ. Sci. Technol., 43, 4934-4939, 2009.

Hunt, G. R., Salisbury, J. W., and Lenhoff, C. J.: Visible and nearinfrared spectra of minerals and rocks: V. Halides, Phosphates, Arsenates, Vanadates and Borates, Modern Geology, 3, 121-132, 1972.

Islam, K. R., Weil, R. R., Mulchi, C. L., and Glenn, S. D.: Freezedried soil extraction method for the measurement of microbial biomass, C. Biol. Fertil. Soils, 24, 205-210, 1997.

Keppler, F., Eiden, R., Niedan, V., Pracht, J., and Schöler, H.F.: Halocarbons produced by natural oxidation processes during degradation of organic matter, Nature, 403, 298-301, 2000.

Keppler, F., Borchers, R., Pracht, J., Rheinberger, S., and Schöler, H. F.: Natural formation of vinyl chloride in the terrestrial environment, Environ. Sci. Technol., 36, 2484-2490, 2002.

Keppler, F., Harper, D. B., Röckmann, T., Moore, R. M., and Hamilton, J. T. G.: New insight into the atmospheric chloromethane budget gained using stable carbon isotope ratios, Atmos. Chem. Phys., 5, 2403-2411, doi:10.5194/acp-5-2403-2005, 2005.

Loh, W. and Shih, Y.: Split selection methods for classification trees, Statistica Sinica 7, 815-840, 1997.

Löw, F., Navratil, P., and Bubenzer, O.: Landscape dynamics in the southern Aralkum desert - using MODIS time series for 
land cover change analysis, in: Aralkum - A man-made desert: The desiccated floor of the Aral Sea (Central Asia), edited by: Breckle, S. W., Wucherer, L., Dimeyeva, L., and Ogar, N. P., Ecological Studies Series, 218, Springer, 83-96, 2012.

Melack, J. M., Hess, L. L., Gastil, M., Forsberg, B. R., Hamilton, S. K., Lima, I. B. T., and Novo, E. M. L. M: Regionalization of methane emissions in the Amazon basin with microwave remote sensing, Glob. Change Biol., 10, 530-544, 2004.

Metternicht, G. I. and Zinck, J. A.: Remote sensing of soil salinity: Potentials and constraints, Remote Sens. Environ., 85, 1-20, 2003.

Metternicht, G. I. and Zinck, J. A.: Remote sensing of soil salinization, CRC Press, 2009.

Mees, F. and Singer, A.: Surface crusts on soils/sediments of the southern Aral Sea basin, Uzbekistan, Geoderma, 136, 152-159, 2006.

Morley, C. R., Trofymow, J. A., Coleman, D. C., and Cambardella, C.: Effects of freeze-thaw stress on bacterial populations in soil microcosms, Microb. Ecol., 9, 329-340, 1983.

Müller, G. and Gastner, M.: The "Karbonat-Bombe", a simple device fort he determination of the carbonate content in sediments, soils and other materials, N. Jb. Miner. Mh., 10, 466-469, 1971.

Micklin, P. P.: The Aral Sea Disaster, Annu. Rev. Earth Pl. Sc., 35, 47-72, 2007.

Micklin, P. P.: The past, present, and future Aral Sea. Lakes \& Reservoirs, Research and Management, 15, 193-213, 2010.

Orlovsky, N., Glantz, M., and Orlovsky, L.: Irrigation and land degradation in the Aral Sea basin, in: Sustainable land use in deserts, edited by: Breckle, S. W., Veste, M., and Wucherer, W., Springer, 52-69, 2001.

Razakov, R. and Kosnazarov, K.: Dust and salt transfer from the exposed bed of the Aral Sea and measures to decrease its environmental impact, in: The Aral Sea basin, edited by: Micklin, P. P. and Williams, W. D., NATO ASI Series, 2., Env., 12, 95-103, 1996.

Rhew, R. C., Miller, B. R., and Weiss, R. F.: Natural methyl bromide and methyl chloride emissions from coastal salt marshes, Nature, 403, 292-295, 2000.

Schmid, T., Koch, M., Gumuzzio, J., and Mather, P. M.: A spectral library for a semi-arid wetland and its application to studies of wetland degradation using hyperspectral and multispectral data, Int. J. Remote Sens., 25, 2485-2496, 2004.

Schöler, H. F. and Keppler, F.: Abiotic formation of organohalogens during early diagenetic processes, in: The handbook of Environ. Chem. The natural production of organohalogen compounds, edited by: Hutzinger, O. and Gribble, G. W., Springer Verlag, Heidelberg, 3(P), 63-84, 2003.
Singer, A., Zobeck, T., Poberrezky, L., and Argaman, E.: The PM10 and PM2.5 dust generation potential of soils/sediments in the southern Aral Sea basin, Uzbekistan, J. Arid Envir., 54, 705-728, 2003.

Sivanpillai, R. and Latchininsky, V.: Mapping locust habitats in the Amudarya river delta, Uzbekistan with multi-temporal MODIS imagery, Environ. Manag., 39, 876-886, 2007.

Stow, D., Hope, A., Boynton, W., Phinn, S., Walker, D., and Auerbach, N.: Satellite-derived vegetation index and cover type maps for estimating carbon dioxide flux for arctic tundra regions, $\mathrm{Ge}$ omorphology, 21, 313-327, 1998.

Varner, R. K., Crill, P. M., Talbot, R. W., and Shorter, J. H.: An estimate of the uptake of atmospheric methyl bromide by agricultural soils, Geophys. Res. Lett., 26, 727-730, 1999.

von Glasow, R. and Crutzen, P. J.: Tropospheric halogen chemistry, in: Treatise on Geochemistry Update 1, (4.02), edited by: Holland, H. D. and Turekian, K. K., Elsevier-Pergamon, Oxford, 1-67, 2007.

Weissflog, L., Lange, C. A., Pfennigsdorff, A., Kotte, K., Elansky, N., Lisitzyna, L., Putz, E., and Krueger, G.: Sediments of salt lakes as new source of volatile highly chlorinated C1/C2 hydrocarbons, Geophys. Res. Lett., 32, L01401, doi:10.1029/2004GL020807, 2005.

Williams, W. D.: Environmental threats to salt lakes and the likely status of inland saline ecosystems in 2025, Environ. Conserv., 29, 154-167, 2002.

Wishkerman, A., Gebhardt, S., McRoberts, C. W., Hamilton, J. T. G., Williams, J., and Keppler, F.: Abiotic methyl bromide formation from vegetation and its strong dependence on temperature, Environ. Sci. Technol., 42, 6837-6842, 2008.

Wucherer, W. and Breckle, S. W.: Vegetation dynamics on the dry sea floor of the Aral Sea, in: Sustainable land use in deserts, edited by: Breckle, S. W., Veste, M., and Wucherer, W., Springer, 52-69, 2001.

Yokouchi, Y., Noijiri, Y, Barrie, L. A., Toom-Sauntry, D., Machida, T., Inuzuka, Y., Akimoto, H., Li, H. J., Fujinuma, Y., and Aoki, S.: A strong source of methyl chloride to the atmosphere from tropical coastal land, Nature, 403, 295-298, 2000.

Zhang, Y., Wang, Y. Y., Su, S. L., and Li, C. S.: Quantifying methane emissions from rice paddies in Northeast China by integrating remote sensing mapping with a biogeochemical model, Biogeosciences, 8, 1225-1235, doi:10.5194/bg-8-12252011, 2011. 